\title{
OPTIMIZING THE PROCESS PARAMETERS OF FRICTION STIR BUTT WELDED JOINT ON ALUMINUM ALLOY AA6061-T6
}

\author{
K.Venkata Kalyani ${ }^{1}$, K.Sunil Ratna Kumar ${ }^{2}$, K.V.P.P.Chandu ${ }^{3}$, S.V.Gopala Krishna ${ }^{4}$ \\ ${ }^{l}$ M.E student, Department of mechanical engineering, CRR College of Engg, Eluru \\ ${ }^{2}$ Assistant professor, Department of mechanical engineering, Eluru, West Godavari, Andhra Pradesh-534007, India \\ ${ }^{3}$ Assistant professor, Department of mechanical engineering, Eluru, West Godavari, Andhra Pradesh-534007, India \\ ${ }^{4}$ Assistant professor, Department of mechanical engineering, Eluru, West Godavari, Andhra Pradesh-534007, India
}

\begin{abstract}
This paper deals with Friction stir welding of AA6061-T6Aluminum Alloy by using H13 Tool at different rotational speeds and welding feeds \&pin diameters. Experiments were conducted according to L9 Orthogonal array which was suggested by Taguchi. Optimum parameters for optimum Tensile strength, Hardness and ductility were found with the help of $S / N$ ratios. Therefore optimization of input process parameter is required to achieve good quality of welding. In this experiment the effect of process parameters on welded joint was studied and optimizes the parameter by using Taguchi method for tensile strength, hardness, ductility. Assign the rank to each factor which are having more influence on the mean of tensile strength, hardness and ductility
\end{abstract}

Keywords: FSW, Taguchi, DOE, Tensile Strength, Hardness, Ductility.

\section{INTRODUCTION}

To produce a joint stronger than the fusion arc welded joint, the Friction Stir Welding process (FSW) can be used. Many applications such as aerospace, automotive and ship building industries, [1] widely use the friction stir welding to weld the lightweight materials, such as aluminum, magnesium and titanium. More effective welding and joining techniques are essential, however for further usage of magnesium alloys. Commonly encountered defects in fusion welded joints [2] such as oxide inclusions, porosity, cracks and distortions surrounding the tool must be hot, so that a successful can be reduced using the joining technique of (FSW), because it has a great potential for magnesium alloys. To develop quality joints, the process variables like the rotational speed, travel speed and tool geometry are vital [3].

Friction stir welding is a solid state welding process invented by The Welding Institute (TWI) of UK in 1991. The work pieces that are to be joined are clamped together on a backing plate. A rotating non consumable tool with a profiled pin and large concentric shoulder slowly plunged in to the joint line between two plates which are clamped together. Here coalescence is created by the combined action of frictional heating between tool and work pieces and the plastic deformation of base metal due to the rotation of the tool. $95 \%$ of heat generated in the process is transferred to the work piece and only $5 \%$ flows in to the tool [4]. The friction heat generated softens the material around the pin and moves it from the front of the pin to the back due to the rotation and translation of the tool.

In conventional welding, dissimilar metals are very difficult to join because of different physical and chemical properties of base metals. The heat generated in the fusion welding process and the subsequent microstructure changes are the main reason for the decay of mechanical properties like strength, hardness and ductility of welded components. Similarly fusion welding of aluminum leads to poor solidification, microstructure and porosity in the fusion zone. Friction stir welding overcomes majority of the limitations of conventional fusion welding processes and in addition extensive thermo mechanical deformations induces dynamic recrystallization and recovery that refines the stir region. Therefore friction stir welded joints have improved mechanical properties such as tensile strength, ductility, hardness than conventional fusion welded joints [5]. Taguchi methods developed by Genichi Taguchi to improve the quality of manufacturing goods are recently applied to the field of engineering, biotechnology, marketing and advertising. The Taguchi method is a very powerful tool for carrying out experimental design. The main aim of the Taguchi methods is to produce an optimum result by analyzing the statistical data which have been given as an input function. This method allows limited number of experimental runs by utilizing a well balanced experimental design called orthogonal array design and signal to noise $(\mathrm{S} / \mathrm{N})$ ratio. Taguchi methods have been successfully utilized by Lakshminarayanan et.al.[6] for optimizing the process parameters of friction stir welding of RDE-40 aluminum alloy. The result shows that the rotational speed, welding speed and axial forces are the main parameters which affect the tensile strength of the joint. Vinod Kumar et.al.[7].

\section{EXPERIMENTAL DETAILS}

The specimens of the size of $80 \mathrm{~mm} \times 75 \mathrm{mmx} 3 \mathrm{~mm}$ were machined from AA6061 aluminum alloy plates. The two plates of AA6061 aluminum alloy were Friction stir welded in the butt configuration by using conventional vertical 
milling machine. The base material's chemical composition is given in Table 1.The table 2 shows the chemical composition of the tool. The Ultimate Tensile Testing machine and hardness testing machine were used to test the tensile strength, elongation and hardness. The Table 3 below shows the identified process parameters and their levels. The L9 orthogonal array is selected as per standard suggested by Taguchi approach and is shown in table4.

Table 1.Base material AA6061 Chemical composition:-

\begin{tabular}{|l|l|l|l|l|l|l|l|l|l|}
\hline $\begin{array}{l}\text { M } \\
\text { g }\end{array}$ & Si & Fe & Cu & Zn & Ti & Mn & Cr & $\begin{array}{l}\text { Othe } \\
\text { rs }\end{array}$ & Al \\
\hline 0.8 & 0.4 & 0. & 0.1 & 0.2 & 0.1 & 0.1 & 0.0 & 0.05 & 98. \\
- & - & 7 & $5-$ & 5 & 5 & 5 & $\begin{array}{l}4- \\
0.3\end{array}$ & & \\
1.2 & 0.8 & & 0.4 & & & & & \\
& & & & & & & & \\
\hline
\end{tabular}

Table 2.Tool H13 Chemical composition:-

\begin{tabular}{|l|l|l|l|l|l|l|l|}
\hline $\begin{array}{l}\text { Element } \\
\text { s }\end{array}$ & $\mathrm{C}$ & $\mathrm{Mn}$ & $\mathrm{Cr}$ & $\mathrm{Mo}$ & $\mathrm{V}$ & $\mathrm{Si}$ & $\mathrm{Fe}$ \\
\hline$\%$ & $\begin{array}{l}0.4 \\
0\end{array}$ & $\begin{array}{l}0.3 \\
5\end{array}$ & $\begin{array}{l}5.2 \\
0\end{array}$ & $\begin{array}{l}1.3 \\
0\end{array}$ & $\begin{array}{l}0.9 \\
5\end{array}$ & $\begin{array}{l}1.0 \\
0\end{array}$ & $\begin{array}{l}\text { Remaind } \\
\text { er }\end{array}$ \\
\hline
\end{tabular}

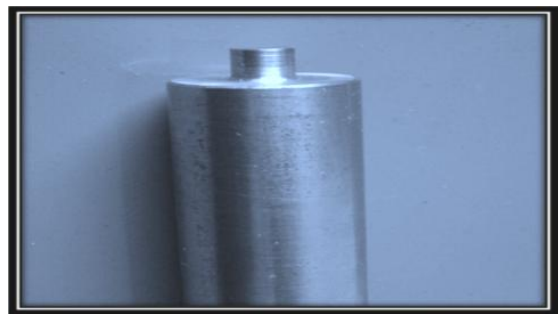

Fig 1A: Straight cylindrical tool

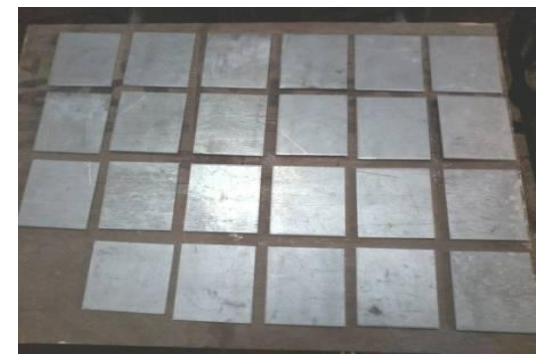

Fig (1B): Aluminum Work pieces

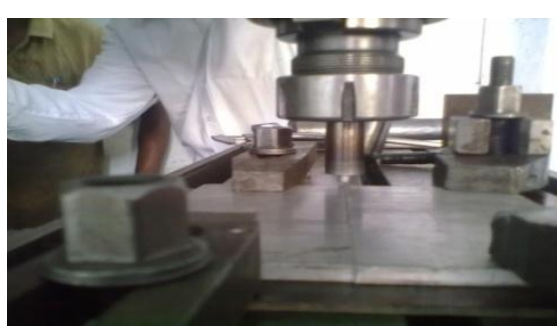

Fig (1C): FSW process

Fig 1.Illustration of FSW components

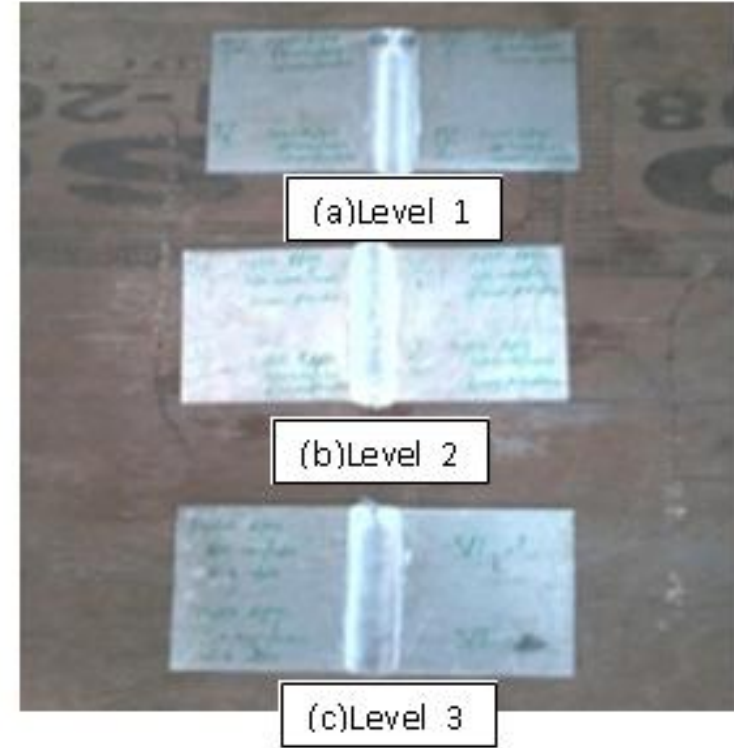

Fig 2 FSW Butt welded joints

\section{OPTIMIZATION OF FSW:}

\subsection{Selection of FSW Parameters and Levels}

To evaluate the optimum conditions of FSW process parameters with respect to FSW butt weld quality; in this study, there are three primary controllable factors and their three levels [8] and [9] are shown in Table 3. The plan of the experiments as shown in Table 4. As per Taguchi techniques, only 9 experiments for L9 orthogonal arrays are needed for percentage of elongation (\%) and ultimate tensile strength (MPa) and hardness (Rockwell). By neglecting the values of the initial and the end pieces from each set of 2 piece trial under same experimental condition, averaged ultimate tensile strength and hardness are calculated and are shown in Table 5. The resulting averaged elongation rate is shown in Table 6.The objective of using Taguchi technique was to reduce the time and cost to evaluate the optimum welding conditions [9].

Table 3: FSW PROCESS PARAMETERS LEVELS

\begin{tabular}{|c|c|c|c|c|}
\hline SI.NO. & $\begin{array}{c}\text { Welding } \\
\text { parameters }\end{array}$ & Level 1 & Level 2 & Level 3 \\
\hline 1 & $\begin{array}{c}\text { Tool rotational } \\
\text { speed N rpm }\end{array}$ & 1120 & 1400 & 1800 \\
\hline 2 & $\begin{array}{c}\text { Tool feed } \\
\text { F(mm/min) }\end{array}$ & 25 & 45 & 50 \\
\hline 3 & $\begin{array}{c}\text { Pin diameter D } \\
(\mathrm{mm})\end{array}$ & 2.5 & 4 & 6 \\
\hline
\end{tabular}

\subsection{Selection of Orthogonal Array}

Based on the number of factors and levels a suitable Taguchi orthogonal array for the experiment is selected by using MINITAB 16 statistical software. Since there are three factors having three levels each, L9 OA is chosen as shown in table 4 [10]. 
Table 4: Orthogonal array for L9 Taguchi Design

\begin{tabular}{|l|l|l|l|}
\hline $\begin{array}{l}\text { S1. } \\
\text { no }\end{array}$ & $\begin{array}{l}\text { Tool } \\
\text { rotational } \\
\text { speed } \\
(\mathrm{rpm})\end{array}$ & $\begin{array}{l}\text { Tool feed } \\
(\mathrm{F})(\mathrm{mm} / \mathrm{min})\end{array}$ & $\begin{array}{l}\text { Pin } \\
\text { diameter } \\
(\mathrm{D})(\mathrm{mm})\end{array}$ \\
\hline 1 & 1 & 1 & 1 \\
\hline 2 & 1 & 2 & 2 \\
\hline 3 & 1 & 3 & 3 \\
\hline 4 & 2 & 1 & 2 \\
\hline 5 & 2 & 2 & 3 \\
\hline 6 & 2 & 3 & 1 \\
\hline 7 & 3 & 1 & 3 \\
\hline 8 & 3 & 2 & 1 \\
\hline 9 & 3 & 3 & 2 \\
\hline
\end{tabular}

\subsection{Experiment Procedure}

Taguhi analysis is performed according to the selected design of experiment table. The maximum tensile strength, hardness developed in each set of combinations is noted and tabulated in table 5[11]. For each experiment in the orthogonal array, signal to noise $(\mathrm{S} / \mathrm{N})$ ratio is calculated. The quality response is mainly divided in to three main types; the larger-the better (LTB), the smaller-the better (STB) and the nominal-the best (NTB) [12] and [13].

$$
\begin{array}{ll}
\text { SNS } & =-10_{\log 10}\left(1 / k \sum_{r=1}^{k}\left(y^{2} i_{r}\right)\right) \text { for } S T B \\
\text { SNS } & =10_{\log 10}\left(\mathrm{~S}_{\mathrm{i}}^{2} / \overline{\mathrm{y}}_{\mathrm{i}}^{2}\right) \text { for } N T B \\
\text { SNS } & =-10_{\log 10}\left(1 / k \sum_{r=1}^{k}\left(1 / y^{2} i_{r}\right) \text { ) for } L T B\right.
\end{array}
$$

Where $y_{i}$ is the calculated average and $S_{i}$ is the standard deviation. $y_{\text {ir }}$ indicates at the $i^{\text {th }}$ experiment or measured characteristic value. $\mathrm{k}$ denotes the number of measurements. The $\mathrm{S} / \mathrm{N}$ ratio is calculated based on LTB criterion and tabulated in the table 5 . The $\mathrm{S} / \mathrm{N}$ ratio is calculated based on STB criterion and tabulated in the table 6[14] and [15].

\section{RESULTS AND DISCUSSIONS}

In the present study the effect of process parameters on the tensile strength, hardness, ductility was examined. The experimental results of tensile strength, hardness were transferred to $\mathrm{S} / \mathrm{N}$ ratio. The $9 \mathrm{~S} / \mathrm{N}$ ratios were tabulated in the table 5. The experimental results of ductility were transferred to $\mathrm{S} / \mathrm{N}$ ratio. The $9 \mathrm{~S} / \mathrm{N}$ ratios were tabulated in the table 6. Statistical software MINITAB is used for calculating mean and S/N ratio by using the LBT and SBT criterion. Then the graphs are plotted as shown in the fig 3, $4 \& 5$. According to Taguchi's idea, maximizing signal to noise ratio will get maximum robustness. The main effects of all control variables are obtained from the graph.
Table 5 Experimental results for tensile strength, hardness and $\mathrm{S} / \mathrm{N}$ ratios of FSW butt welds

\begin{tabular}{|l|l|l|l|l|l|l|l|}
\hline Runs & N & F & D & $\begin{array}{l}\text { Tensile } \\
\text { strength } \\
\left(\mathrm{N} / \mathrm{mm}^{\wedge} 2\right)\end{array}$ & $\begin{array}{l}\text { S/N } \\
\text { Ratio }\end{array}$ & $\begin{array}{l}\text { Hardness } \\
(\mathrm{RHN})\end{array}$ & $\begin{array}{l}\text { S/N } \\
\text { Ratio }\end{array}$ \\
\hline 1 & 1120 & 25 & 2.5 & 112.65 & 41.03 & 46 & 33.25 \\
\hline 2 & 1120 & 40 & 4 & 141.47 & 43.01 & 49.125 & 33.82 \\
\hline 3 & 1120 & 50 & 6 & 129.83 & 42.27 & 52 & 34.32 \\
\hline 4 & 1400 & 25 & 4 & 151.68 & 43.62 & 45 & 33.06 \\
\hline 5 & 1400 & 40 & 6 & 157.66 & 43.95 & 45.125 & 33.08 \\
\hline 6 & 1400 & 50 & 2.5 & 123.33 & 41.82 & 56.75 & 35.07 \\
\hline 7 & 1800 & 25 & 6 & 153.83 & 43.74 & 47.125 & 33.46 \\
\hline 8 & 1800 & 40 & 2.5 & 115.57 & 41.26 & 47.875 & 33.60 \\
\hline 9 & 1800 & 50 & 4 & 136.78 & 42.72 & 49.25 & 33.84 \\
\hline
\end{tabular}

Larger is better for tensile strength and hardness

$$
\mathrm{S} / \mathrm{N}=-10_{\log 10}\left(1 / k \sum_{r=1}^{k}\left(1 / y^{2} i_{r}\right)\right)
$$

From the above signal to noise ratios of each level of factor it is concluded that the optimum factor level to achieve Optimum tensile strength is $157 \mathrm{MPa}$.which are having maximum s/n ratios i.e. speed is 1400 R.P.M and Feed is 40 $\mathrm{mm} / \mathrm{min}$ and pin diameter is $6 \mathrm{~mm}$. Optimum factor level to achieve Optimum Hardness is 56.which are having maximum s/n ratios i.e. speed is 1400 R.P.M and Feed is 50 $\mathrm{mm} / \mathrm{min}$ and pin diameter is $2.5 \mathrm{~mm}$.

Response Table for Signal to Noise Ratios Larger is better

\begin{tabular}{|l|l|l|l|}
\hline Level & SPEED(N) & FEED(F) & $\begin{array}{l}\text { PIN } \\
\text { DIAMETER(D) }\end{array}$ \\
\hline 1 & 42.11 & 42.80 & 41.37 \\
\hline 2 & 43.13 & 42.74 & 43.12 \\
\hline 3 & 42.57 & 42.27 & 43.32 \\
\hline Delta & 1.03 & 0.53 & 1.95 \\
\hline Rank & 2 & 3 & 1 \\
\hline
\end{tabular}

From the delta values it assigns the rank to each factor which are having more influence on the mean of tensile strength, from the results of $\mathrm{S} / \mathrm{N}$ ratio also it is observed that pin diameter is the dominant factor for tensile behavior.

Response Table for Signal to Noise RatiosLarger is better

\begin{tabular}{|l|l|l|l|}
\hline Level & SPEED(N) & FEED(F) & $\begin{array}{l}\text { PIN } \\
\text { DIAMETER(D) }\end{array}$ \\
\hline 1 & 33.80 & 33.26 & 33.98 \\
\hline 2 & 33.74 & 33.51 & 33.58 \\
\hline 3 & 33.64 & 34.42 & 33.62 \\
\hline Delta & 0.16 & 1.15 & 0.40 \\
\hline Rank & 3 & 1 & 2 \\
\hline
\end{tabular}


From the delta values it assigns the rank to each factor which are having more influence on the mean of hardness, from the results of $\mathrm{S} / \mathrm{N}$ ratio also it is observed that tool traverse feed is the dominant factor for hardness distribution.

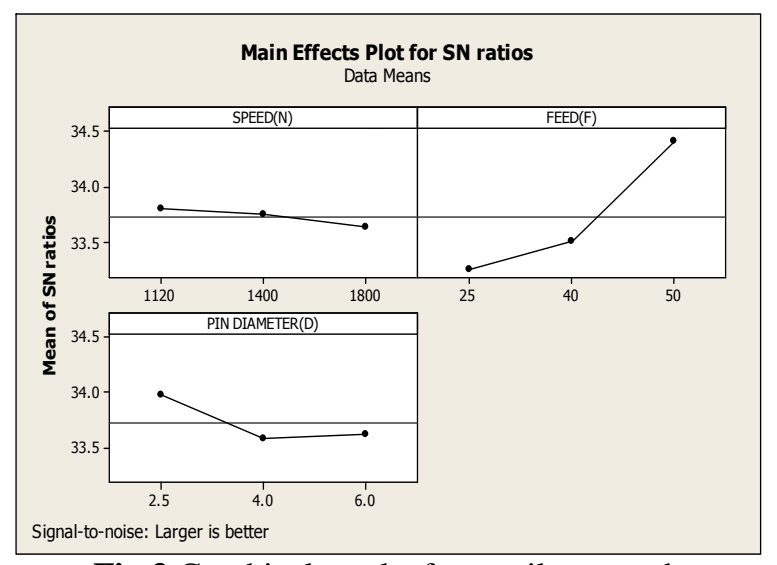

Fig 3. Graphical results for tensile strength

Based on the above graph, the optimum conditions for the tensile strength are (a): $1120 \mathrm{rpm}$ speed (b):50 $\mathrm{mm} / \mathrm{min}$ feed (c): 2.5 pin diameter.

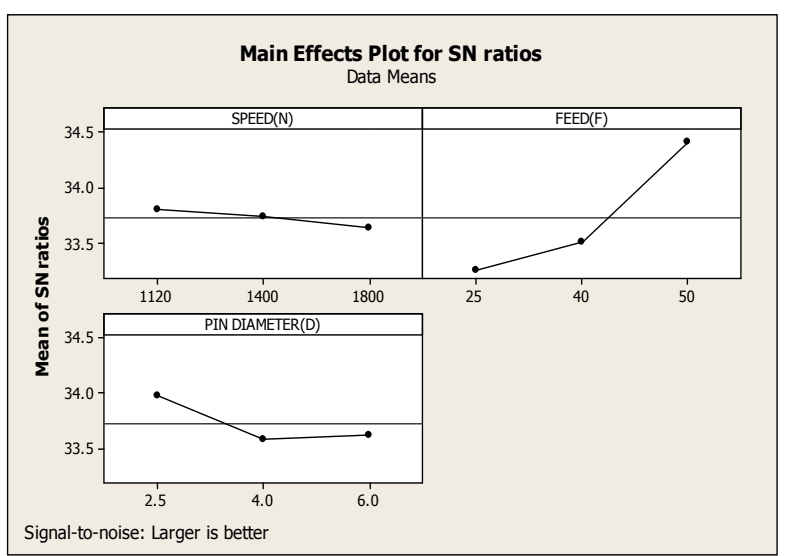

Fig 4. Graphical results for hardness

Based on the above graph, the optimum conditions for the hardness are (a): $1120 \mathrm{rpm}$ speed (b):50mm/min feed (c): 2.5 pin diameter.

Table 6 Experimental results for (\%of elongation) and $\mathrm{S} / \mathrm{N}$ ratios of FSW butt welds

\begin{tabular}{|l|l|l|l|l|l|}
\hline Runs & N & F & D & Ductility(\%) & $\begin{array}{l}\text { S/N } \\
\text { Ratio }\end{array}$ \\
\hline 1 & 1120 & 25 & 2.5 & 33.33 & -30.45 \\
\hline 2 & 1120 & 40 & 4 & 36.66 & -31.28 \\
\hline 3 & 1120 & 50 & 6 & 26.66 & -28.51 \\
\hline 4 & 1400 & 25 & 4 & 30 & -29.54 \\
\hline 5 & 1400 & 40 & 6 & 33.33 & -30.45 \\
\hline 6 & 1400 & 50 & 2.5 & 25 & -27.95 \\
\hline 7 & 1800 & 25 & 6 & 31.66 & -30.01 \\
\hline 8 & 1800 & 40 & 2.5 & 21.66 & -26.71 \\
\hline 9 & 1800 & 50 & 4 & 28.33 & -29.046 \\
\hline
\end{tabular}

Smaller is better for \%elongation

$$
\left.\mathrm{S} / \mathrm{N} \quad=-10_{\log 10} 1 / k \sum_{r=1}^{k}\left(y^{2} i_{r}\right)\right)
$$

From the above signal to noise ratios of each level of factor it is concluded that the optimum factor level to achieve Optimum \%of elongation is 21.66.which are having maximum $\mathrm{s} / \mathrm{n}$ ratios i.e. speed is 1800 R.P.M and Feed is 50 $\mathrm{mm} / \mathrm{min}$ and pin diameter is $4 \mathrm{~mm}$.

Response Table for Signal to Noise Ratios Smaller is better

\begin{tabular}{|l|l|l|l|}
\hline Level & SPEED(N) & FEED(F) & $\begin{array}{l}\text { PIN } \\
\text { DIAMETER(D) }\end{array}$ \\
\hline 1 & 30.09 & 30.00 & 28.38 \\
\hline 2 & 29.32 & 29.49 & 29.96 \\
\hline 3 & 28.59 & 28.51 & 2966 \\
\hline Delta & 1.50 & 150 & 1.58 \\
\hline Rank & 2 & 3 & 1 \\
\hline
\end{tabular}

From the delta values it assigns the rank to each factor which are having more influence on the mean of \%of elongation, from the results of $\mathrm{S} / \mathrm{N}$ ratio also it is observed that pin diameter is the dominant factor for ductility.

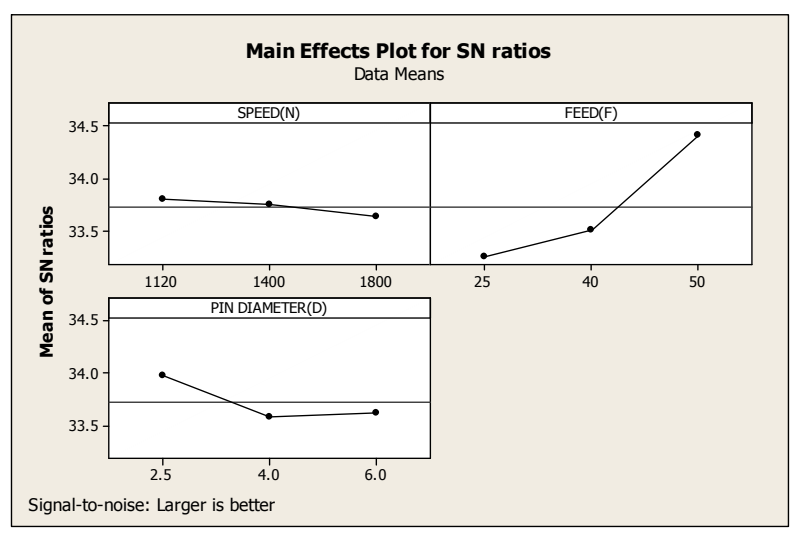

Fig 5: Graphical results for ductility

Based on the above graph, the optimum conditions for the hardness are (a): 1800rpm speed (b): $25 \mathrm{~mm} / \mathrm{min}$ feed (c): $4 \mathrm{~mm}$ pin diameter.

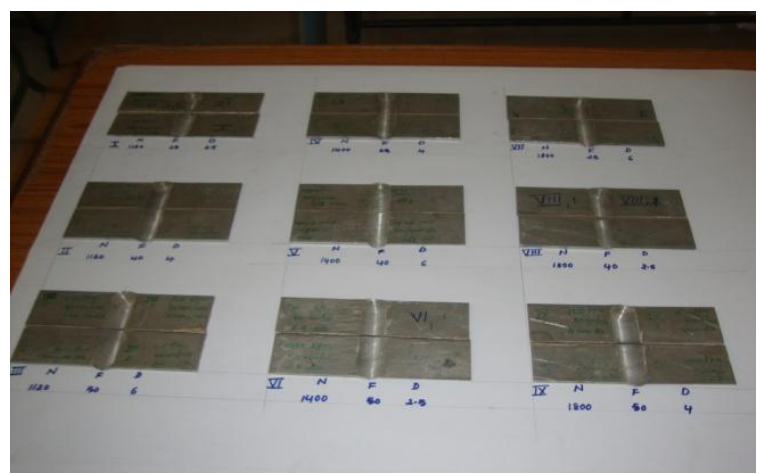

Fig: 6 Samples of testing pieces 


\section{CONCLUSION}

The butt joining of Aluminum alloy was successfully carried out using FSW technique. The samples were characterized by mechanical properties like tensile strength, hardness, ductility. The following conclusions were made from the present investigation.

$>\quad$ I Observed that the tool traverse feed having more influence on the mean of tensile strength. And Mean of Hardness.

Observed that the pin diameter having more influence on the mean of \%elongation.

Observed that the $1400 \mathrm{rpm}, 40 \mathrm{~mm} / \mathrm{min}$ feed and $6 \mathrm{~mm}$ pin diameter was best to maximize the tensile strength.

Observed that the $1400 \mathrm{rpm}, 50 \mathrm{~mm} / \mathrm{min}$ feed and $2.5 \mathrm{~mm}$ pin diameter was best to maximize the hardness.

Observed that the $1800 \mathrm{rpm}$ and $50 \mathrm{~mm} / \mathrm{min}$ feed and $4 \mathrm{~mm}$ pin diameter was best to minimize the ductility.

\section{ACKNOWLEDGEMENTS}

The authors would like to thankful to the members of CRR college of Engg, Eluru, India for their help and support during the experiments and suggestions in preparation of the paper.

\section{REFERENCES}

[1]. Dayong Kim, wonoh Lee and Juneheyung Kim, 2010. Chongmin Kim and Formability of evaluation of friction stir welded 6111-T4 sheet with respect joining material direction. International Journal of Mechanical Science, doi:10. 1016/j.i jmecsci. 2010. Maharashtra Institute of Technology, India, 2009.01.00.

[2]. Zhang, H., S.B. Lin, L. Wu, J.C. Feng and S.H.L. Ma, 2006. Defects formation procedure and mathematical model for defect free friction stir welding of magnesium alloy, Materials and Design, 27: 805-809.

[3]. Mahmoud, T.S., A.M. Gaafer and T.A. Khalifa, 2011. Effect of tool rotational and welding speeds on microstructural and mechanical characteristics of friction stir welded A319 cast Al alloy, Materials Science and Technology, 24(5): 553-559

[4]. Chao. Y.J., Qi. X, and Tang, W.2003. Heat transfer in friction stir welding -Experimental and numerical studies, Transaction of the ASME, pp.125.138-145

[5]. Lee WB, Yeon YM, Jung SB. The improvement of mechanical properties of frction stir welded A356 Al alloy. Master Sci Eng 2003; A355:154-9.

[6]. A. K. Lakshminarayanan, V. Balasubrahmanyan. Process parameters optimization for friction stir welding of RDE-40 aluminum alloy using Taguchi technique; Trans.Nonferrous Met.Soc China 2008.18. 548-554

[7]. Vinod Kumar vankanti, Venkateswarlu ganta; Optimization of process parameters in drilling of GFRP composite using Taguchi method; Journal of material research and technology.2014;3(1);35-41.
[8]. D.M. Rodrigues, A. Loureiro, C. Leitao, R.M. Leal, B.M. Chaparro, and P. Vilaca, "Influence of friction stir welding parameters on the micro-structural and mechanical properties of AA 6016-T4 thin welds," J. for Mater. And Des. vol. 30, pp. 1913-1921, 2009.

[9]. F. Sarsilmaz, and U. Caydas, "Statistical analysis on mechanical properties of friction stir welded AA1050/AA5083 couples," Int. J. of Adv. Manuf. Tech., vol. 43, pp. 248-255, 2008.

[10]. Samir K. Panda, Polymer Chandrasekhar \& Dr. Saranjit Singh "Finite Element Simulation of Friction Stir Butt Welding of AA4047 Aluminum Plates"

IRACST - Engineering Science and Technology: An International Journal (ESTIJ), ISSN: 2250-3498, Vol.2, No.6, and December 2012.

[11]. P.Prasanna, Dr.Ch.Penchalayya, Dr.D.Anandamohana Rao" Optimization and Validation of Process Parameters in Friction Stir Welding on AA 6061 Aluminum Alloy Using Gray Relational Analysis" International Journal of Engineering Research and Applications (IJERA) ISSN: 2248-9622, Vol. 3, Issue 1, January -February 2013, pp.1471-1481.

[12]. Y.S. Sato, and H. Kokawa, "Distribution of tensile property and micro-structure in friction stir weld of 6063 aluminum," Metall. and Mater. Trans., vol. 32, pp. 941-948, 2001.

[13]. D.M. Rodrigues, A. Loureiro, C. Leitao, R.M. Leal, B.M. Chaparro, and P. Vilaca, "Influence of friction stir welding parameters on the micro-structural and mechanical properties of AA 6016-T4 thin welds," J. for Mater. And Des., vol. 30, pp. 1913-1921, 2009.

[14]. Renju Mohan1, N. R. Rajesh2, Satheesh Kumar S3 “ Finite element modeling for maximum temperature in friction stir welding of AA1100 and optimization of process parameter by Taguchi method" IJRET: International Journal of Research in Engineering and Technology, eISSN: 23191163 | pISSN: 2321-7308.

[15]. G.Surya Prakash Rao1, B.Balu Naik2, Abhijith Datta3 "Optimizing the process parameters of friction stir welded joint of Magnesium Alloy AZ31B " IJRET: International Journal of Research in Engineering and Technology Eissn: 2319-1163 | pISSN: 2321-7308

\section{BIOGRAPHIES}

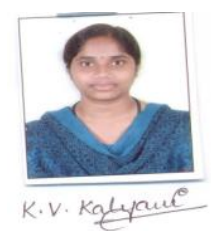

K.Venkata kalyani was born in Eluru in India, on Sep 03, 1991. She was graduated from V.R.Siddhartha College of Engineering, Vijayawada in 2012 and student of M.E MACHINE DESIGN at SIR C.R Reddy College of Engg, Eluru India. My areas of interest are Design, Friction stir welding, related topics.

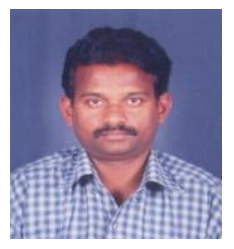

K.Sunil Ratnakumar working as a Asst.Proffessor in SIR C.R.R.College of Engineering. 


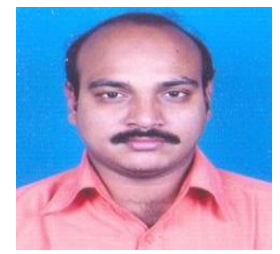

K.V.P.P.Chandu working as a

Asst.Proffessor in SIR C.R.R.College

of Engineering

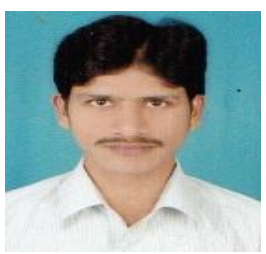

S.V.Gopala Krishna working as a

Asst.Proffessor in SIR C.R.R.College of

Engineering 